\title{
PAINTED POTTERY WEST OF THE KIZILIRMAK: NOTES ON CHRONOLOGY AND SUPRA-REGIONAL CONTACTS AT THE TURN OF THE 3RD TO THE 2ND MILLENNIUM BC
}

\section{KIZILIRMAK'IN BATISINDAKI BOYALI KERAMIKLER: M.Ö. 3.'DEN 2. BiN'E GEÇIŞ KRONOLOJISI ÜZERIINE NOTLAR VE BÖLGELERARASI BAĞLANTILAR}

\author{
Makale Bilgisi Article Info \\ Başvuru: 10 Kasım 2020 Received: November 10, 2020 \\ Hakem Değerlendirmesi: 10 Kasım 2020 Peer Review: November 10, 2020 \\ Kabul: 01 Aralık 2020 Accepted: December 01, 2020
}

DOI : 10.22520/tubaar2020.27.004

Jan-Krzysztof BERTRAM* - Gülçin İGEZDi BERTRAM**

This article is dedicated to our dear colleague Prof. Dr. Sevil Gülçur.

\begin{abstract}
This article presents dark (black/black-brown) and bichrome (black/black-brown and red) painted pottery appearing west of the Kizllirmak in the late Early Bronze Age and during the transition to the Middle Bronze Age. The pottery originated from the excavations at Karaoğlan Höyük, Polatlı Höyük, Gordion, Külhöyük, and Çayyolu Höyük. The dark-painted pottery might be connected to the Intermediate ware and emerged at the mentioned sites at the end of the Early Bronze Age and during the transition to the Middle Bronze Age. Two groups (Çayyolu Bichrome Ware A and $\mathrm{B}=\mathrm{CBW} A$ and $\mathrm{B}$ ) which differ in their motifs (simple lines and hatched bands) have been distinguished in the bichrome-painted pottery. Both bichrome groups are local phenomena and appear at about the same time as the black/ black-brown-painted ceramics. A supra-regional comparison of ÇBW A and B with other ceramic groups is difficult, but a comparison with Alişar III-pottery might be possible.
\end{abstract}

Keywords: Central Anatolia, Late 3rd Millennium BC, Early Bronze Age, Transition to Middle Bronze Age, Painted Pottery, Intermediate Style, Çayyolu Höyük.

Prof. Dr., Kırşehir Ahi Evran Üniversitesi, Bağbaş1 Yerleşkesi, Fen-Edebiyat Fakültesi, Arkeoloji Bölümü, TR-40100 Kırşehir, e-posta: janbertram2001@yahoo.de ORCID: 0000-0001-9536-7064

** Doç. Dr., Kırşehir Ahi Evran Üniversitesi, Bağbaşı Yerleşkesi, Fen-Edebiyat Fakültesi, Arkeoloji Bölümü, TR-40100 Kırşehir, e-posta: gilgezdi@yahoo.com ORCID: 0000-0003-3700-3187 


\section{ÖZET}

Bu makale, Kızılırmak'ın batısında yer alan Geç Erken Tunç Çağı ve Orta Tunç Çağı'na Geçiş dönemine tarihlenen koyu (siyah/siyah-kahverengi) ve iki renkli (siyah/siyah-kahverengi ve kırmızı) boyalı çanak çömlekleri kapsamaktadır. Makalenin içeriğindeki malzeme, Karaoğlan Höyük, Polatlı Höyük, Gordion, Külhöyük ve Çayyolu Höyük kazılarından gelmektedir. Koyu renk boyalı çanak çömlekler Intermediate mallar ile ilişkilendirilmelidir. Bu mallar, yukarıda belirtilen buluntu yerlerinde, Erken Tunç Çağı'nın sonunda ve Orta Tunç Çağı'na geçişte görülür. Çift renkli boyalı çanak çömlekler söz konusu olduğunda ise motifleri (basit çizgiler ve tarama bantlar) farklı olan iki grup (Çayyolu Bichrome Mal A ve B = ÇBM A ve B) göze çarpmaktadır. Her iki grup da yerel olgulardır ve yaklaşı olarak siyah/siyah-kahverengi boyalı çanak çömleklerle aynı zamanda görünürler. ÇBM A ve B'nin diğer çanak çömlek grupları ile bölgelerarası düzeyde karşılaştırılması zor olmakla birlikte, Alişar III-keramıkleri ile bir bağlantı kurmak mümkün olabilir.

Anahtar Kelimeler: Orta Anadolu, M.Ö. Geç 3. Bin, Eski Tunç Çağ, Orta Tunç’a Geçiş, Boyalı Çanak Çömlek, Intermediate Stil, Çayyolu Höyük 


\section{INTRODUCTION ${ }^{1}$}

In the late Early Bronze Age and during the transition to the Middle Bronze Age, painted pottery quite frequently occurs in a variety of forms within the Kizilırmak arch. Several painting styles can be distinguished here (Intermediate ware, Alişar III, and others). ${ }^{2}$ Moreover, for a long time the dark-painted pottery of this period has been known to extend further to the west. It was found at Karaoğlan Höyük, ${ }^{3}$ and remains of painted vessels were also found at Polatlı Höyük. ${ }^{4}$ Later, similar pottery was identified at Gordion. ${ }^{5}$ With the excavations at Çayyolu Höyük, a new site west of the Kizılırmık has been added (Table 1). ${ }^{6}$ In the years from 2011 to 2015, the authors, in cooperation with the Anadolu Medeniyetleri Müzesi in Ankara, were able to conduct excavations on this settlement. Thereby an extensive stratigraphy for the 3rd millennium $\mathrm{BC}$ was documented, covering the period from the Late Chalcolithic/Early Bronze Age I to the transition to the Middle Bronze Age. ${ }^{7}$ In addition to Alişar and Alaca Höyük, Çayyolu is thus one of the few sites in Central Anatolia where such an extensive settlement sequence for the 3rd millennium $\mathrm{BC}$ has been documented. There is a great amount of painted pottery from Çayyolu II (late Early Bronze Age and transition to the Middle Bronze Age). Since comprehensive lay-

\footnotetext{
1 For the support of our work we thank here the T. C. Kültür ve Turizm Bakanlığı, Kültür Varlıkları ve Müzeler Genel Müdürlüğü. Our thanks also go to our colleagues at the Ankara Anadolu Medeniyetleri Müzesi, Yozgat Müzesi, and Konya Müzesi. We would also like to thank Prof. Dr. H. Cambel and Prof. Dr. M. Özdoğan (İstanbul) for providing the Hashöyük finds for processing. We participated in numerous fruitful discussions with Dr. S. Omura and Dr. M. Omura (both of the Japanese Institute of Anatolian Archaeology, Kaman) and were able to gain insight into the latest excavation results of the Early Bronze Age. This study includes results from BAPprojects funded by Kurşehir Ahi Evran University (ProjectCode PYO-FEN.4001.12.037, PYO-FEN.4001.13.010, PYO-FEN.4001.15.003) and Orta Doğu Teknik Üniversitesi (Project-Code BAP-07.03.2009.03, 2763). The drawings were made by T. Tekin (Ankara) and M. Ülker (Ankara). B. Zafer (Ankara) helped with the statistical analysis of the ceramic finds from Çayyolu Höyük. The linguistic correction of this article was kindly undertaken by N. Umm-Süleyman Peaci (Düzce). We would like to thank all the people involved in the project for their support over the years.
}

2 E.g., Öktü 1973; Özgüç 1947; von der Osten 1937: 151-177, 230-258; Omura 1991

3 Arık 1939: Plate LII lower right; Orthmann 1963a: 24, 121, Plate 20,4/08. For the location of all sites in Central Anatolia mentioned here, see Bertram/İlgezdi Bertram in press: Plate 31.

4 Lloyd/Gökçe 1951: Fig. 13,1-8.

5 Gunter 1991: 20-21, Fig. 4, nos. 56 and 64.

6 There is painted pottery from Karayavşan and Ilıca (Orthmann 1966: Figs. 8,6-8). Although similar, the painted pottery exhibits other characteristics and therefore is not to be considered here. 7 Bertram/Ilgezdi Bertram 2018. er observations and correlations are available, much more detailed statements can now be made about the character and dating of the painted pottery west of the Kızılırmak. During the excavations at Çayyolu Höyük, different types of painted pottery were found which, on the one hand show local features, but on the other hand, also indicate relationships to the east, i.e., east of the Kiz1lirmak. At this point we want to examine in more detail the occurrence of painted pottery west of the Kizılirmak in the late Early Bronze Age and during the transition to the Middle Bronze Age.

\section{SITES WITH PAINTED POTTERY: KARAOĞLAN HÖYÜK, POLATLI, GORDION, KÜLHÖYÜK}

We have long been aware of painted pottery finds originating from some older excavations. However, their allocation to layers and their chronological classification is not always clear. From Karaoğlan Höyük there is a remnant of a vessel whose body is decorated with black/brown painting. There is a chessboard pattern on the neck and below it an angular band consisting of three lines. R. O. Arık ${ }^{8}$ attributed the vessel to the Hittite settlement. Chronologically, however, it should be dated into the period of time discussed here. ${ }^{9}$ In Polat1, dark-painted pottery (a handful of shards with black painting) appears in layers 13 to $22 .{ }^{10}$ The painting shows lines that are arranged horizontally, in groups and/or as angular bands. The vessel remains mentioned were labelled "Cappadocian Painted Ware" or "Alişar III" pottery. ${ }^{11}$ Bronze Age strata were explored in the PN-3 sondage at the Gordion settlement. Several painted vessel remains that show brown painting were recovered from level 7 . Here again, the familiar motif of groups of lines arranged in angular bands is evident. Another shard shows a band filled with a crosshatch design. ${ }^{12}$ In the recent past, the excavations at Külhöyük carried out by the Anadolu Medeniyetleri Müzesi south of Ankara and not far from Haymana have also revealed Early Bronze Age strata. Here, lines and line groups can also be seen on the pottery. On larger vessel fragments they are clearly arranged as angular bands. ${ }^{13}$

\footnotetext{
Arık 1939: Plate LII.

9 According to Orthmann 1963a: 24 an allocation to a find layer is unclear.

10 Lloyd/Gökçe 1951: Table on p. 33.

11 Lloyd/Gökçe 1951: Table on p. 33 and p. 51.

12 Gunter 1991: 20-21 and Fig. 4/nos. 56 and 64.

13 Denizli/Kaya/Çetin 2002/2003: Plate XV/Fig. 25; Denizli/ Kaya/Çetin 2006: Plate XIV/Fig. 19 (lower middle); Temizsoy/ Kaya/Çetin 2002: Plate IX/Fig. 14.
} 


\begin{tabular}{|l|l|l|l|}
\hline \multicolumn{1}{|c|}{ Site } & \multicolumn{1}{|c|}{ Layer } & \multicolumn{1}{c|}{ Finds } \\
\hline Karaoğlan Höyük & ?, "Hittite" & $\begin{array}{l}\text { Lessel with angular } \\
\text { band and painted chess- } \\
\text { board-like pattern }\end{array}$ & $\begin{array}{l}\text { Arık 1939: Plate LII; Orth- } \\
\text { mann 1963a: 24, 121, Plate } \\
20,4 / 08\end{array}$ \\
\hline Polatlı Höyük & Level 13 to 22 & $\begin{array}{l}\text { Painted black lines, line } \\
\text { groups and angular bands }\end{array}$ & $\begin{array}{l}\text { Lloyd/Gökçe 1951: Table } \\
\text { on p. 33, p. 51, and Fig. } \\
13,1-8\end{array}$ \\
\hline $\begin{array}{l}\text { Gordion, } \\
\text { PN-3 }\end{array}$ & Level 7 & $\begin{array}{l}\text { Brown-painted pottery } \\
\text { with line decoration/ angu- } \\
\text { lar bands and cross-hatch- } \\
\text { ing }\end{array}$ & $\begin{array}{l}\text { Gunter 1991: 20-21, Fig. 4, } \\
\text { nos. 56 and 64 }\end{array}$ \\
\hline
\end{tabular}

Table 1: Overview of painted pottery finds west of the Kızılırmak / Kızllırmak'ın batısındaki boyalı keramik buluntulara genel bakış

\section{PAINTED POTTERY AT ÇAYYOLU HÖYÜK}

\section{STRATIGRAPHY OF THE SETTLEMENT}

The höyük is located in the south of Ankara, about 200 $\mathrm{m}$ west of Alacaatli Caddesi. It is one of the smaller settlements, with a diameter of $150 \times 150 \mathrm{~m}$ and a height of about $8.5 \mathrm{~m}$. The well-known settlements of Ahlatlibel and Koçumbeli are only about $9 \mathrm{~km}$ to the southeast. Based on the pottery, four phases of the settlement could be distinguished at Çayyolu. As the oldest, Phase IV dates to the Late Chalcolithic/Early Bronze Age I. Phase III covers the Ahlatlibel-Koçumbeli horizon, which corresponds, as previously assumed, to the Early Bronze Age II/III (early), but whose origins probably go back to the Early Bronze Age I (late). Phase II corresponds to the late Early Bronze Age and the transition to the Middle Bronze Age. More recent finds, which were very rarely encountered, are summarized in Phase I. Of importance for us in this study are the layers of Phase II that were uncovered over a larger area in the south of the höyük. Extensive settlement and building remains were found in trenches G5, H4-5, and I4-5 (Fig. 1). In H-I4 and 5 a multi-room building was uncovered (Fig. 2). However, to give one coherent stratigraphy of layers is not possible. The layers are not evenly distributed horizontally, but are found in irregular steps. Therefore, layer sequences must be given separately for H5, G5, and H4/ I4-5. The manner in which they can be connected is not clear. The most extensive sequence is from trench H5. The lowest layers belong to Phase III, and thus, a complete sequence has been documented here of the layers from Phase II, which are still present today. Building remains were found in trench G5 to the west, but their connection with those from H5 is uncertain. The same applies to the layers in the remaining three trenches (H4, I4, and I5). A reliable correlation with the building layers of the other trenches is not possible because the construction activities at the höyük were locally limited and of varying intensity. ${ }^{14}$

\section{PAINTED POTTERY OF ÇAYYOLU ॥}

For Phase II, i.e., for the late Early Bronze Age and the transition to the Middle Bronze Age, there are many painted vessel remains (Plates 1-10). Occasionally, white painting (Plate 2,2) and Red-cross bowls (Plate 4,3) have been found. Far more numerous are vessels with dark (black/brown) painting on a light background as well as bichrome, i.e., black/brown- and red-painted pottery. ${ }^{15}$

\section{Pottery with dark painting on a light background}

Within this group, motifs consisting of lines and line groups predominate (Plates 1; 2,1 and 3-6; 3; 5,1; 10,1 and 4 ). Since these are only smaller vessel remains, it is scarcely possible to make statements about the entire motif. The motifs that are seen range from those which are relatively carefully and regularly executed (e.g., Plate $2,5)$, to those which are sometimes less carefully painted (Plate 3,4) and display groups of lines that barely run parallel (Plates 1,5 and 10,4). In some cases, the motifs may have been augmented in order to form angled bands, such as those found in Gordion (e.g., Plates 2,3 and 10,1).

\footnotetext{
14 For more detail, see Bertram/İlgezdi Bertram in press: chapter on Çayyolu Höyük.

15 From G5, H5, I4-5, H4-5 (= areas where Çayyolu II layers are present), a total of more than 1.5 tons of pottery or more than 55,000 vessel remnants were obtained. There are at least 37 shards of vessels with dark-painted decoration (about $1.5 \mathrm{~kg}$ ) and at least 27 shards of vessels with bichrome-painting (about $2 \mathrm{~kg}$ ). Despite the quite high number of vessel remains (64 pieces), this shows that the percentage of dark- and bichromepainted ceramics is quite low. The statistical evaluation of the ceramics has not yet been completed. Therefore the information given here may still change, if only slightly. However, the changes should not have a significant influence on the overall picture.
} 


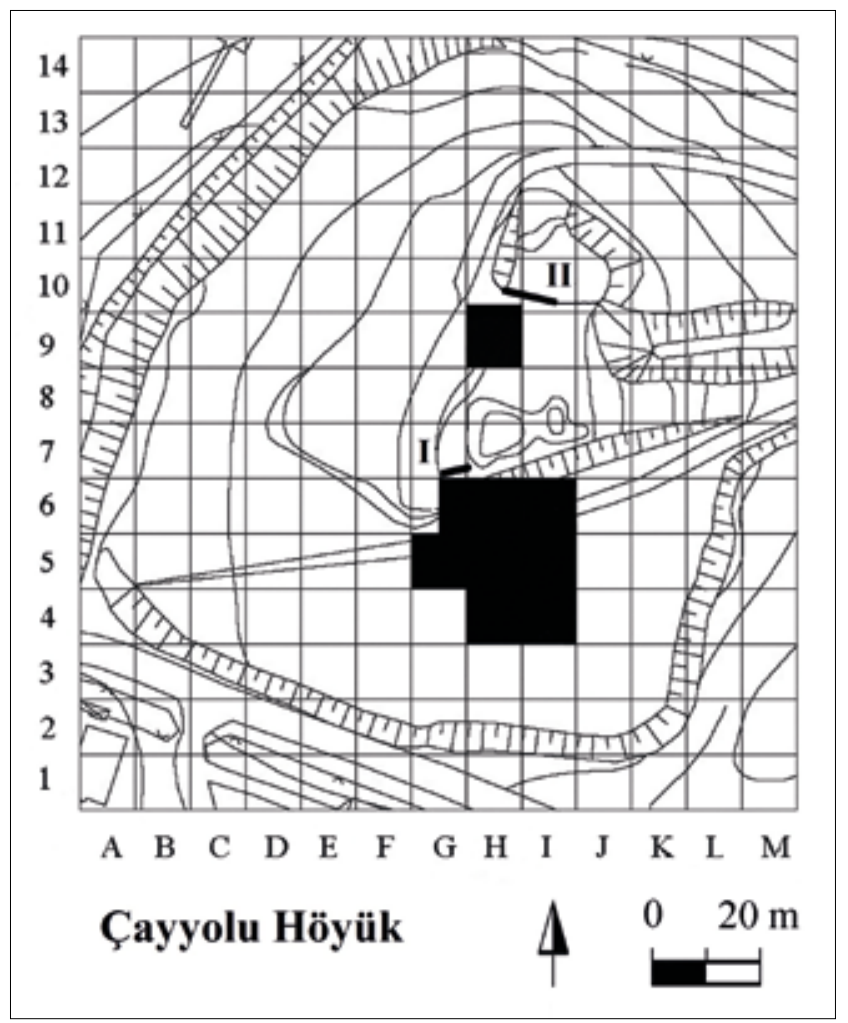

Figure 1: Çayyolu Höyük. Topographical plan with the location of the excavation trenches and two profiles (thick black lines). Bertram/İlgezdi Bertram in press: Fig. 31 / Çayyolu Höyük. Kazılan açmalar ve iki profilin (kalın siyah çizgi) konumunu gösteren topografik plan. Bertram/Ilgezdi Bertram in press: Fig. 31

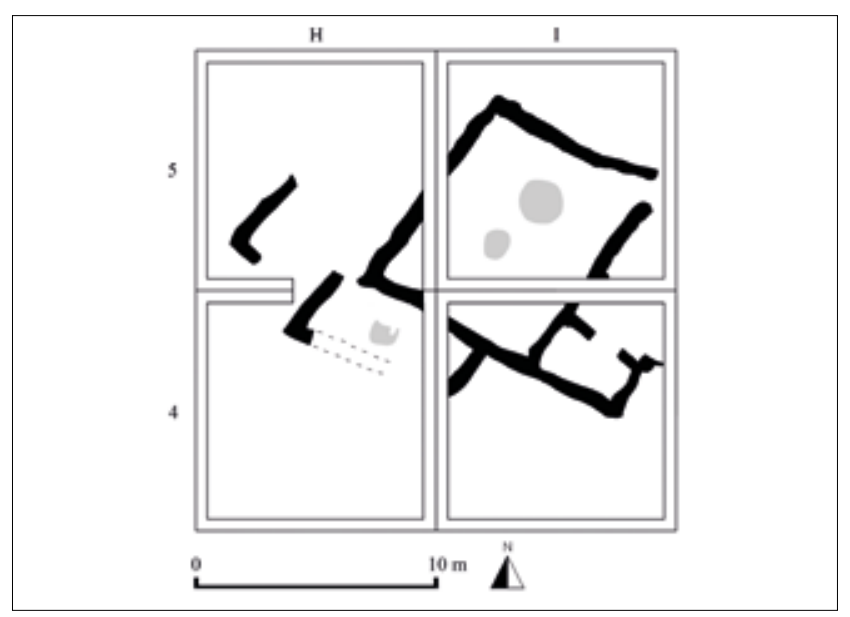

Figure 2: Çayyolu Höyük. Simplified plan of architectural remains of a house in trenches H4-5/I4-5. Black = wall remains; grey = fire places/ovens. Layer 6 in H-I4-5. Bertram/Ilgezdi Bertram in press: Fig. 36 / Çayyolu Höyük. H4-5/I4-5 açmalarında yer alan bir yapıya ait kalıntıların basitleştirilmiş mimari planı. Siyah $=$ duvar kalıntıları; gri = ates yerleri/ocaklar. H-I4-5'de katman 6. Bertram/İlgezdi Bertram in press: Fig. 36

A singular example is a rim shard with arched and wavy painting (Plate 5,1). The motif on another piece (Plate $3,1)$ perhaps belonged to a ladder pattern. It is difficult to judge to which vessel forms the pieces belonged. One was a bowl (Plate 5,1), another one (Plate 1,1) came from a larger pot. Since many of the shards are relatively thick, it is likely they are mainly from larger pots. The shard with a vertical handle (Plates 1,5 and 10,4) would correspond well to this notion. The ceramic was not very hardfired and has a light, mostly beige/light-gray to slightly yellowish surface, which was smoothed or only slightly polished. The clay may contain sand and lime particles in varying quantities. The colour of the black and blackbrown painting sometimes appears very pale. The pieces shown here were found in $\mathrm{H} 5$ in layers 2, 4 and 7 (Table 2). In G5 they occur in all layers (2, 3A, and 3B; Table 3), whereas in $\mathrm{H} 4$ and I5, they are found only in layer 5 (Table 4). The findings in trenches H5 and G5 indicate that the dark-painted pottery appeared over a longer period of Phase II. However, we currently have no explanation for the conspicuously low number in $\mathrm{H} 4$ and I5.

\section{Bichrome (black/brown and red) painted pottery}

The bichrome painting in black/black-brown and red is characteristic of the ceramics treated in this chapter (Plates 4,1-2; 5,2; 6,1-2 and 4-6; 7-9; 10,2-3). Two groups can be distinguished by their motifs. The first group includes vessels with groups of lines (hereafter referred to as Çayyolu Bichrome Ware A [ÇBW A]). We assign the pitcher (Plate 5,2) to this group, along with other vessels having an $\mathrm{X}$-motif on the front side. Other shards may also have such line groups (e.g., Plates 7,2; 8,2 and 4). The pitcher also clearly shows that the lines were not applied carefully or in parallel. The second group (hereafter referred to as Çayyolu Bichrome Ware B [ÇBW B]) contains hatched bands, which may also be derived from $\mathrm{X}$-like motifs. Two larger rim shards from funnel-necked vessels are present (Plates 4,1-2 and 9,1-2). Apart from the pitcher and the funnel-necked vessels, no further statements can be made about the vessel shapes. The ceramic also displays a rather bright, slightly polished or smoothed surface. The light-gray, beige, and sometimes slightly yellowish background was painted with black to black-brown and red colours, which also appear very pale at times. Since there are only a few stratified shards with bichrome painting, their distribution over the layers is less clearly apparent. The bichrome line ware appears in $\mathrm{H} 4$ in layers 2 and 5 (Table 4). In H5, it is present only in layer 3 (Table 2). The hatched band motif presented here occurred only in trench G5, in layers 3A and 3B.

\section{DARK- AND BICHROME-PAINTED POTTERY IN THE CONTEXT OF CENTRAL ANATOLIA}

To the extent indicated by the finds, the dark-painted pottery is characterized mainly by line motifs such as angular bands and groups of lines varying in quality and 


\begin{tabular}{|c|c|c|c|}
\hline \multirow{2}{*}{ Layer } & \multicolumn{3}{|c|}{ Pottery } \\
\hline & Line decoration & ÇBW A & ÇBW B \\
\hline ÇH H5/1 & \multicolumn{3}{|c|}{ Modern layer } \\
\hline ÇH H5/2 & Plates 1,$1 ; 3,2 ; 3,3$ & & \\
\hline ÇH H5/3 & & Plates 8,1 ?; 8,3 ? & \\
\hline ÇH H5/4 & Plate 3,4 & & \\
\hline ÇH H5/5 & & & \\
\hline ÇH H5/6 & & & \\
\hline ÇH H5/7 & Plates 2,1 ?; 2,3 ?; 5,1 & & \\
\hline ÇH H5/8 & & & \\
\hline ÇH H5/9 & & & \\
\hline ÇH H5/10 & & & \\
\hline ÇH H5/11 & & & \\
\hline \hline
\end{tabular}

Table 2: Çayyolu Höyük. Layer sequence in trench H5 and stratigraphic position of the painted vessel remains / Çayyolu Höyük. H5 açmasının katman dizisi ve boyalı kap parçalarının stratigrafik konumları

\begin{tabular}{|c|c|c|c|c|}
\hline \multirow{2}{*}{\multicolumn{2}{|c|}{ Layer }} & \multicolumn{3}{|c|}{ Pottery } \\
\hline & & Line decoration & ÇBW A & ÇBW B \\
\hline ÇH G5/1 & & \multicolumn{3}{|c|}{ Modern layer } \\
\hline \multicolumn{2}{|l|}{ ÇH G5/2 } & Plate 1,2 & & \\
\hline \multirow[t]{2}{*}{ ÇH G5/3 } & $\mathbf{A}$ & Plates 1,$4 ; 2,5 ; 3,1$ & & Plates 6,$2 ; 8,5$ \\
\hline & $\bar{B}$ & Plate 2,6 & & Plates 4,$1 ; 4,2 ; 7,1 ; 7,3$ \\
\hline
\end{tabular}

Table 3: Çayyolu Höyük. Layer sequence in trench G5 and stratigraphic position of the painted vessel remains / Çayyolu Höyük. G5 açmasının katman dizilimi ve boyalı kap parçalarının stratigrafik konumlarl

\begin{tabular}{|c|c|c|c|}
\hline \multirow[t]{2}{*}{ Layer } & \multicolumn{3}{|c|}{ Pottery } \\
\hline & Line decoration & ÇBW A & ÇBW B \\
\hline ÇH H-I4-5/1 & \multicolumn{3}{|c|}{ Modern layer } \\
\hline ÇH H-I4-5/2 & & Plate 7,5 & \\
\hline ÇH H-I4-5/3 & & & \\
\hline ÇH H-I4-5/4 & & & \\
\hline ÇH H-I4-5/5 & Plates 1,$3 ; 1,5 ; 2,4$ & Plates 5,$2 ; 6,4 ; 6,5 ; 7,2 ; 7,4 ; 8,2 ; 8,4$ & \\
\hline ÇH H-I4-5/6 & & & \\
\hline ÇH H-I4-5/7 & & & \\
\hline ÇH H-I4-5/8 & & & \\
\hline
\end{tabular}

Table 4: Çayyolu Höyük. Sequence of layers in trenches H4, I4, and I5 and stratigraphic position of the painted vessel remains / Çayyolu Höyük. H4, I4 ve I5 açmalarının katan dizilimleri ve boyalı kap parçalarının stratigrafik konumu 


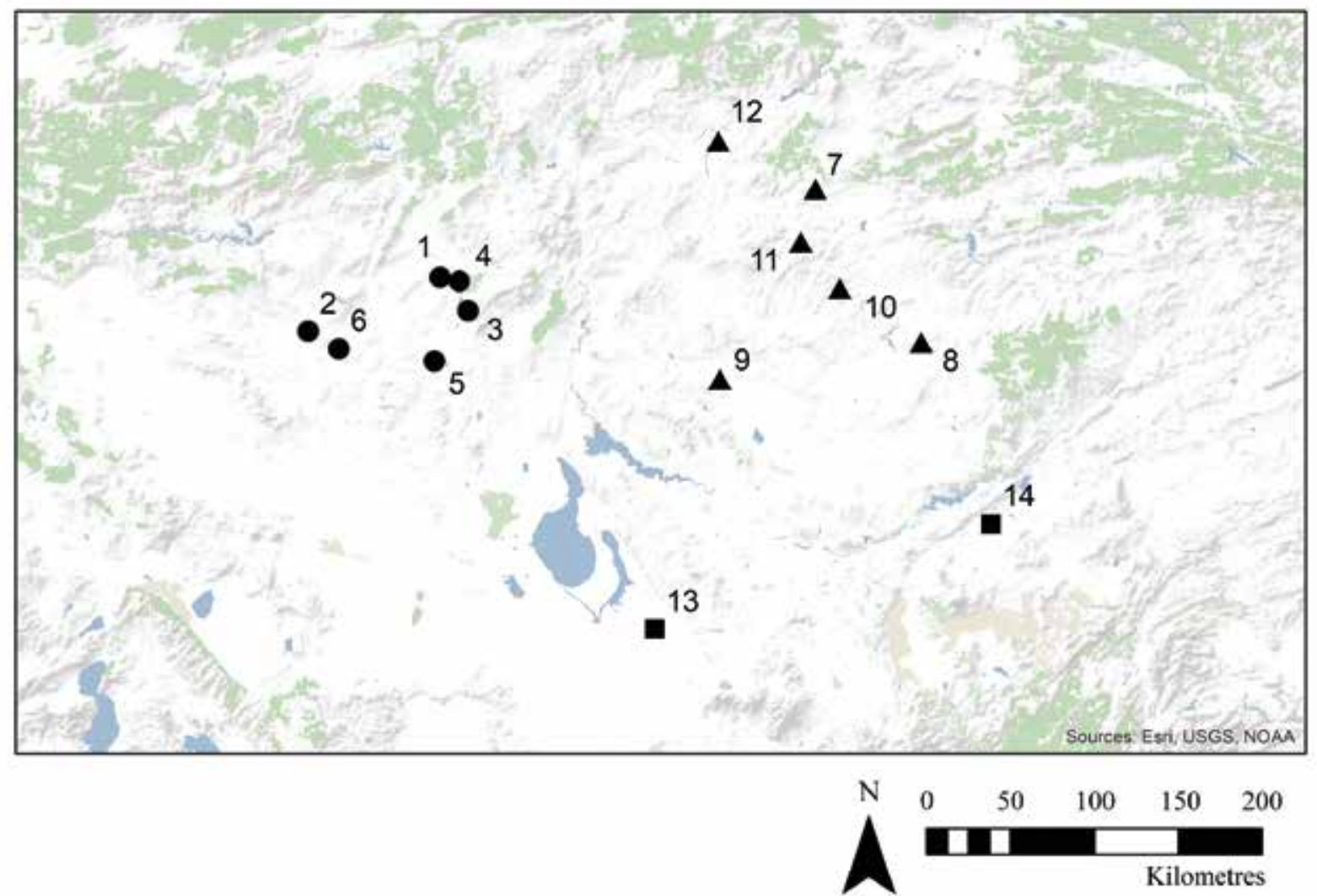

Figure 3: Sites mentioned in the text with Intermediate ware and related pottery / Metinde sözü geçen "Intermediate mallar" ve bununla ilişkili çanak çömleklerin ele geçtiği buluntu yerleri. West of the Kızılırmak (circle) / Kızılırmak'ın batısı (daire): 1 Çayyolu Höyük; 2 Gordion; 3 Karaoğlan Höyük; 4 Koçumbeli ?; 5 Külhöyük; 6 Polatlı Höyük. Within the Kızılırmak arch (triangle) / Kızılırmak kavisi içindeki (üçgen): 7 Alaca Höyük; 8 Alişar; 9 Hashöyük; 10 Mercimektepe; 11 Northwest Slope; 12 Resuloğlu. South of the Klzılırmak (square) / Kızllırmak'ın güneyi (kare): 13 Acemhöyük; 14 Kültepe

quantity. Presumably, the vessels painted were larger; however, there is no clear evidence of smaller vessels such as cups or small bowls. In the publication of the Polatlı finds, there was already a reference to an eastern connection of the dark-painted pottery and a reference to Alişar III-ceramics. This report mentions the introduction of the dark-painted pottery in the "Copper Age". ${ }^{16}$ In fact, there are indications that this kind of decoration appears in the "Copper Age", but probably only towards the end, and then, quite sporadically. ${ }^{17}$ It becomes clear from the compilation of the finds that simple motifs are characteristic of the dark-painted pottery discussed here, which appears in a similar form at all mentioned sites west of the Kizilirmak (Fig. 3). The stratigraphic relationship between the monochrome dark-painted and the bichrome-painted wares is difficult to estimate. The finds from Çayyolu Höyük give only a very diffuse and ambiguous picture. It cannot be deduced with certainty from the distribution whether one of them tends to be older

16 Lloyd/Gökçe 1951: Table on p. 33.

17 Resuloğlu: Yıldırım 2014: 4 and Fig. 6. Koçumbeli: A shard shows traces of painted decoration in the shape of an angle. It was probably originally painted with a dark colour because it has a light beige surface. Alişar: Painted pottery in the late "Copper Age", see von der Osten 1937: 230. or younger. In G5, two groups (monochrome-painted, ÇBW B) appear together in layers $3 \mathrm{~A}$ and B. In trench $\mathrm{H} 4$, the monochrome-painted ceramics appear together with ÇBW $A$ in layer 5 . There are some parallels in Central Anatolia for the cross-hatching, angled bands, and angle motifs in the monochrome black/brown-painted ceramics. These simply structured patterns of lines are associated with the Intermediate ware. Cross-hatching and angular bands are seen in Alişar, ${ }^{18}$ as well as in the Intermediate ware of Hashöyük, ${ }^{19}$ Mercimektepe, ${ }^{20}$ Kültepe, ${ }^{21}$ and the North-Western Slope (layer 9; Fig. 3). ${ }^{22}$ Acemhöyük offers many very good parallels. Comparative finds are distributed over layers $\mathrm{V}$ to $\mathrm{X}$, with a focus on layers V, VIII, and IX. ${ }^{23}$ These six layers cover

18 von der Osten 1937: Figs. 235,6 as well as 236,5 and 8; Orthmann 1963b: 23 and Plate 38,9.

19 We would like to thank Prof. Dr. H. Çambel and Prof. Dr. M. Özdoğan (İstanbul) for giving us the opportunity to evaluate the finds.

20 Material studies at the Yozgat Museum. A publication is in preparation with M. Özcan. We thank the Yozgat Museum staff for their support.

21 Özgüç 1947: Fig. 5.

22 Orthmann 1963b: 22, Plates 5,65 (Layer 9) and 18,70 (Layer 9).

23 Some examples are given here: Kamış 2012: Plates 17,91 (Layer VI), 75,320 (Layer VIII), 135,567 (Layer V), 137,573-574 
the period from the Early Bronze Age IIIA to the end of the Early Bronze Age, while layers VIII and IX are in parallel with Early Bronze Age IIIA. ${ }^{24}$ It is interesting that the above-mentioned simple line decoration from Acemhöyük seems to have had a longer duration, similar to that of Çayyolu.

Therefore, with all this in mind, presumably, the monochrome dark-painted ware presented here can be associated with the Intermediate pottery east of the Kizilırmak (Fig. 3). Of course, the Intermediate ceramics within the Kizılirmak arch also show considerable differences. First and foremost, there is the technique, with the pottery here being fired much harder. There are also differences in the grouping of the lines and their arrangement. The painting is in black, brown to reddish-brown, and reddish colour and by far more carefully executed than the examples from Çayyolu Höyük presented here. Therefore, it seems probable to us that the finds from Karaoğlan, Polatll, Gordion, Külhöyük, and Çayyolu show connections to the Intermediate pottery, but are most likely to be understood as local variants.

For the bichrome-painted ceramics ÇBW $A$ and $B$, it is much more difficult to find parallels. In addition to Çayyolu Höyük, Karaoğlan Höyük is another site where ÇBW $B$ appears. During our survey and prospection work at the site in 2010-2012, a shard was found that undoubtedly shows this hatched motif in black-brown and red colour. It is also likely that there is corresponding pottery at Külhöyük. ${ }^{25}$ Since we have no knowledge of such ceramics from other sites, these could be examples of local expression. However, we must add that excavations recording the transition from the late Early to the Middle Bronze Age are quite rare west of the Kiz1lirmak. Therefore, a wider distribution of bichrome pottery cannot be excluded at present. Since the Early Bronze Age was only recorded in relatively small sondages in Gordion, the lack of bichrome-painted pottery should not be overstressed. Only selected ceramics were published in the report from Polatll, perhaps reflecting only a small part of the find material. Thus it is not clear here whether bichrome pottery was generally absent or whether it was merely not considered for the publication. The pitcher from Çayyolu (ÇBW $A$ ) shows interesting similarities to a vessel from Alişar. ${ }^{26}$ The shapes are quite similar. The piece from Alişar is painted in an Alişar III-style in bi-

(Layer V and VIII), 138,575-576 (Layer IX), 143,593 (Layer VIII), 150,624 (Layer V), 177,734-736 (Layer IX, VIII, X), 178,737-739 (Layer IX, VIII, VIII), 179,740-742 (Layer VIII, VII, V), 180,743-745 (Layer IX, IX, VIII), 181,747-749 (Layer V, VIII, V), 185,768-770 (Layer VIII, VIII, V), 187,778-781 (Layer V, IX, V, V).

24 Kamış 2012: Table on p. 368.

25 Denizli/Kaya/Çetin 2006: Plate XIV/Fig. 19 (lower left)?

26 von der Osten 1937: 254 and Fig. 241,c 226. chrome brown and red. It clearly shows a painted X-motif on the front side, similar to the piece from Çayyolu. With this pitcher from Çayyolu we could have echoes of the Alişar III-style piece, which, and this should be emphasised once again, displays a much superior quality of execution than the Çayyolu Höyük find. Most likely ÇBW $A$ and $B$ are local expressions of a bichrome painting style that finds correspondences in the Alişar III-style east of the Kizilirmak. Such echoes can also be found in the vessel from Karaoğlan Höyük mentioned at the beginning. The chessboard pattern corresponds well to the fragment of a vessel from Hacibektaş/Suluca Karahöyük, ${ }^{27}$ which might be assigned to the Alişar III-style. A jug from Kültepe, layer 11, with such painting has been assigned to the Intermediate style. ${ }^{28}$ Based on the observations made here, the layer sequence of Çayyolu II would be approximately parallel with Acemhöyük V-X, ${ }^{29}$ and perhaps with the late "Copper Age" (?) and layers $5 \mathrm{M}-6 \mathrm{M}$ and $12 \mathrm{~T}$ in Alişar. ${ }^{30} \mathrm{~A}$ parallelization with Kültepe is only roughly possible, since very few finds from the Early Bronze Age have been published to date. Intermediate ware appears in Kültepe for the first time in layer 13 , coming from settlement remains and grave finds, and in layers 12 and 11 it appears in connection with monumental architecture. Vessel forms include simple cups, bowls, two-handled cups, Schnabelkannen, and others. Here, too, the widely used lines and groups of lines (sometimes as angular bands) appear on motifs. Furthermore, triangles and squares as well as large areas covered with painting are also encountered. The Intermediate ware in layer 11 is associated with Alişar III-pottery and then, after this layer, it is replaced by Alişar III-pottery. ${ }^{31}$ The parallelization with Kültepe would probably include approximately at least layers 13 to 11 on the höyük with Intermediate ceramics, but could likely encompass even younger layers with Alişar III-ceramics. ${ }^{32}$

\footnotetext{
27 Özdemir 2016: 175.

28 Öktü 1973: 188-189 and Plate 21.

29 Kamış 2012.

30 von der Osten 1937.

31 Öktü 1973: 38-58 and Plates 1-31.

32 Öktü 1973: 38-41.
} 
PAINTED POTTERY WEST OF THE KIZILIRMAK

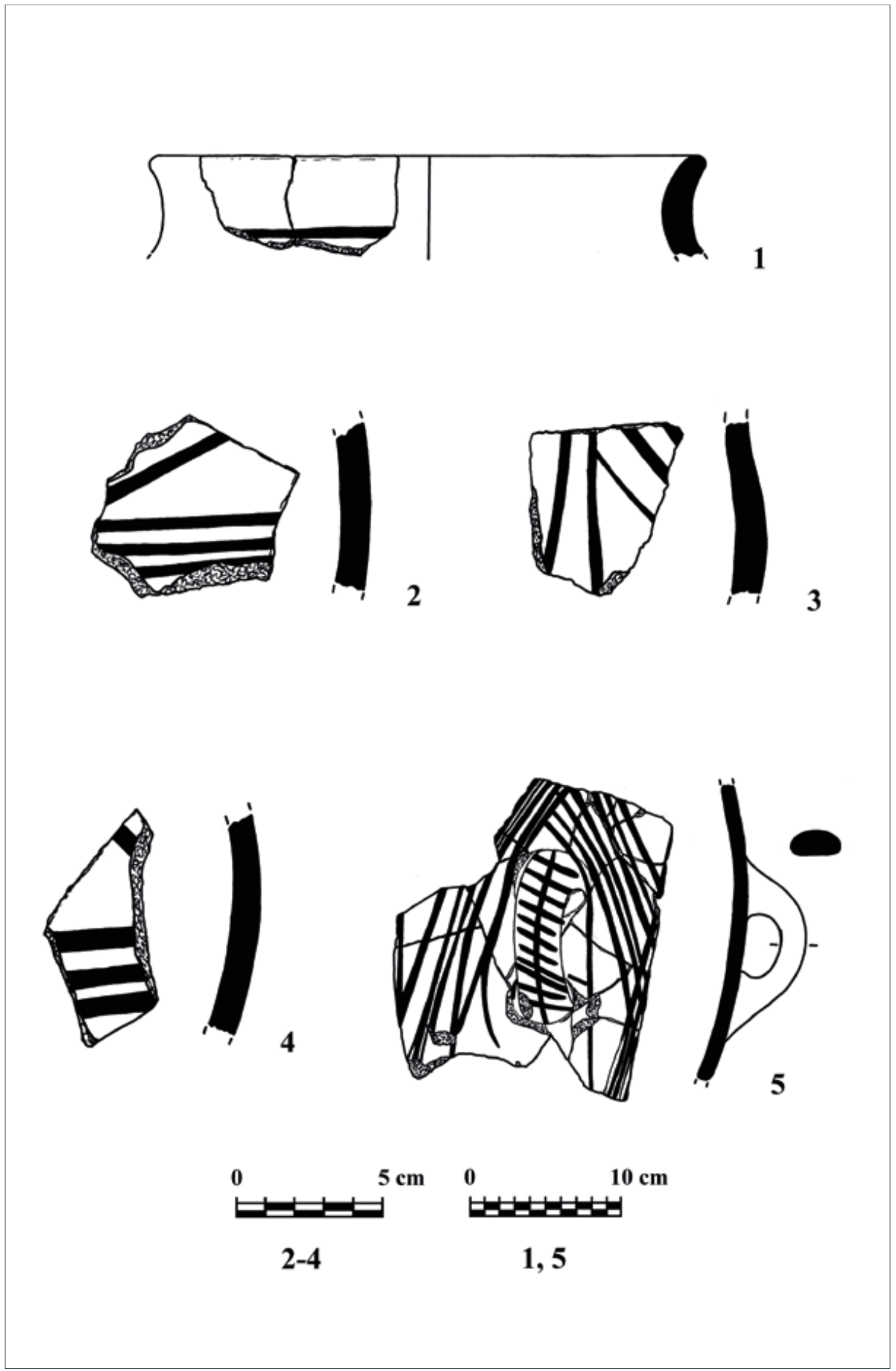

Plate 1: Çayyolu Höyük. Dark-painted pottery / Çayyolu Höyük. Koyu renk boyalı çanak çömlekler 

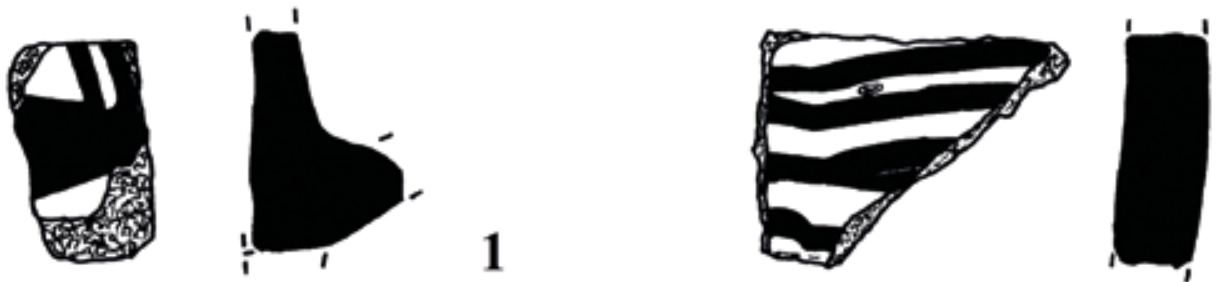

2
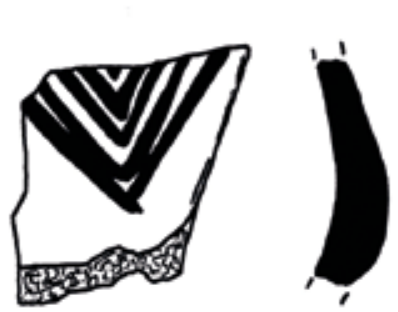

3

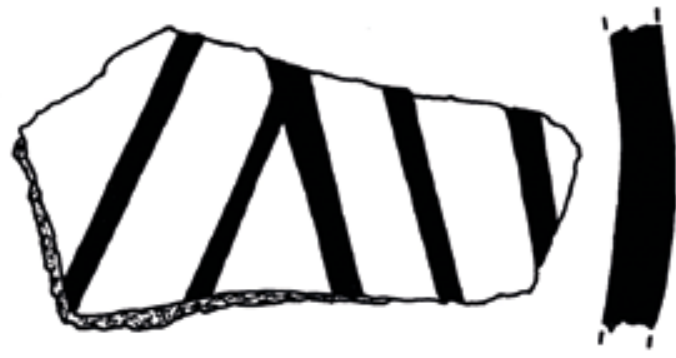

4
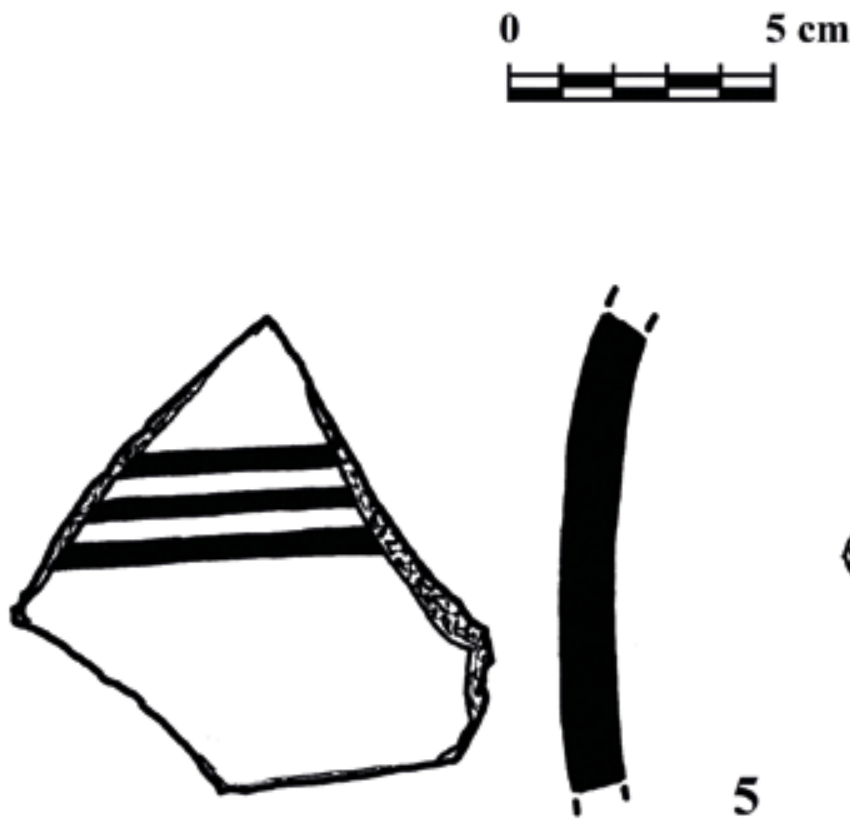

5
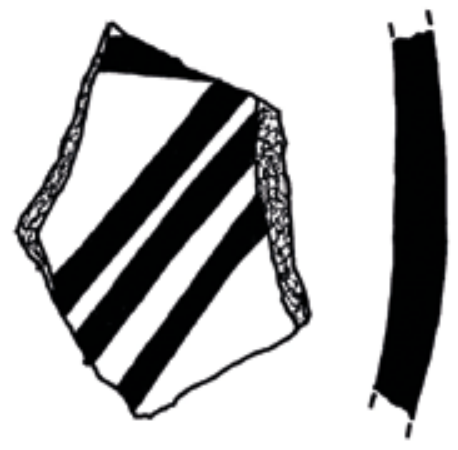

6

Plate 2: Çayyolu Höyük. White- (2) and dark-painted (1, 3-6) pottery / Çayyolu Höyük. Beyaz (2) ve koyu renk (1, 3-6) boyalı çanak çömlekler 
PAINTED POTTERY WEST OF THE KIZILIRMAK

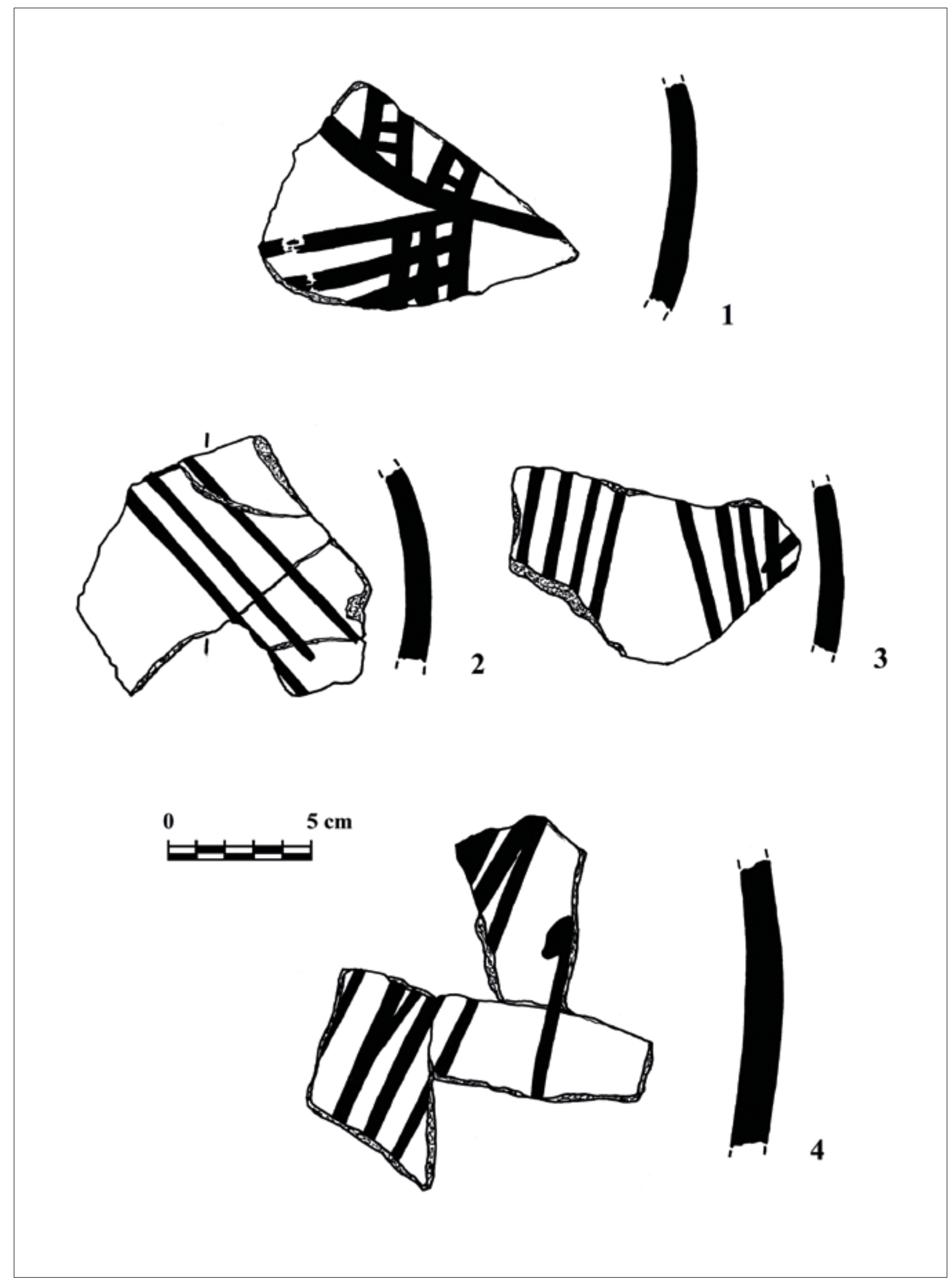

Plate 3: Çayyolu Höyük. Dark-painted pottery / Çayyolu Höyük. Koyu renk boyalı çanak çömlekler 

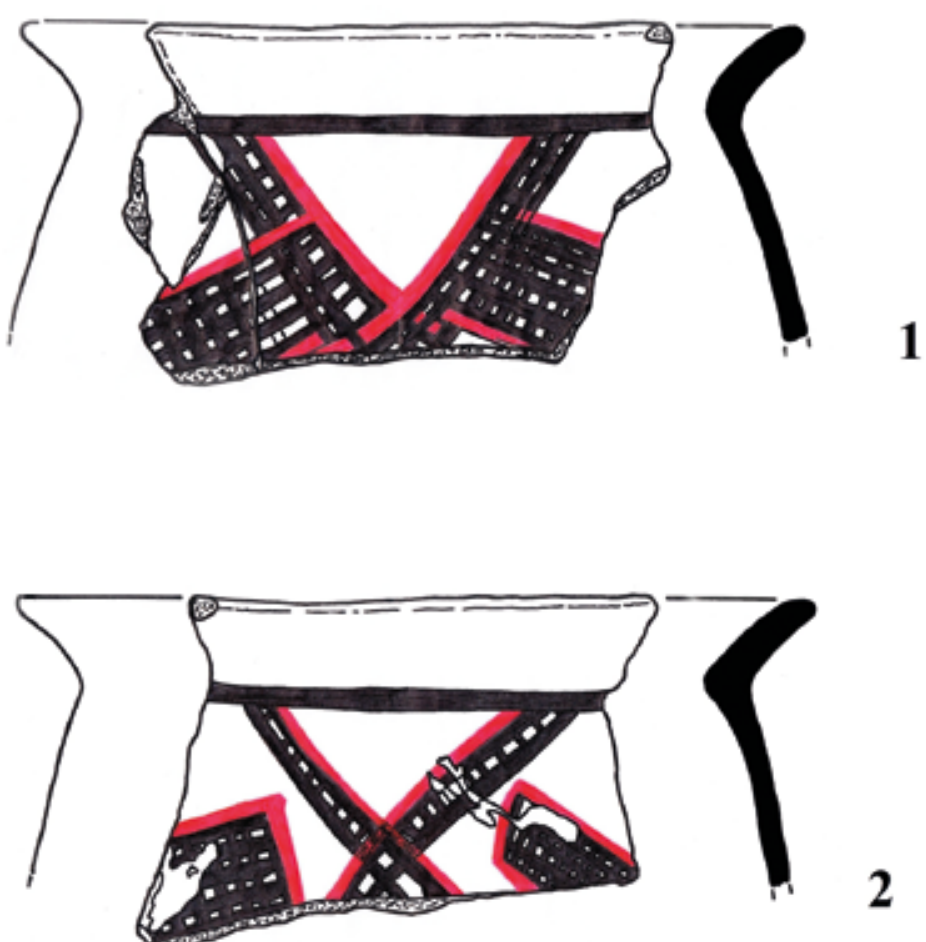

2

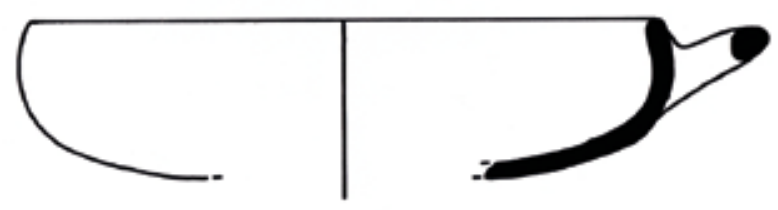

3a-c
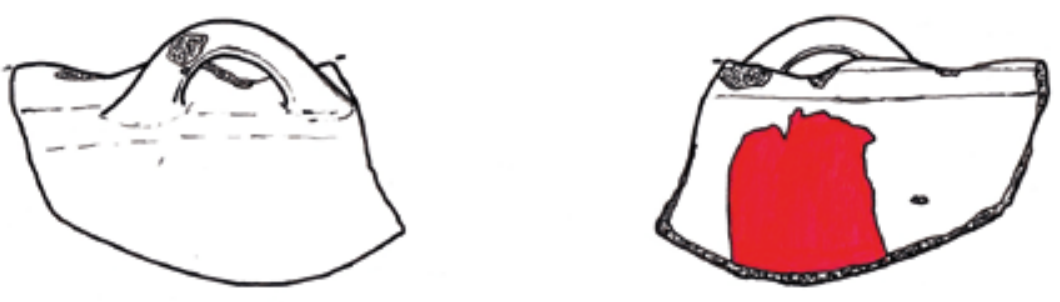

$10 \mathrm{~cm}$

0

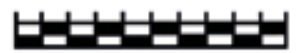

Plate 4: Çayyolu Höyük. Bichrome-painted pottery (1-2) and Red-cross bowl ? (3) / Çayyolu Höyük. İki renkli boyalı çanak çömlekler (1-2) ve Red-cross bowl? (3) 
PAINTED POTTERY WEST OF THE KIZILIRMAK
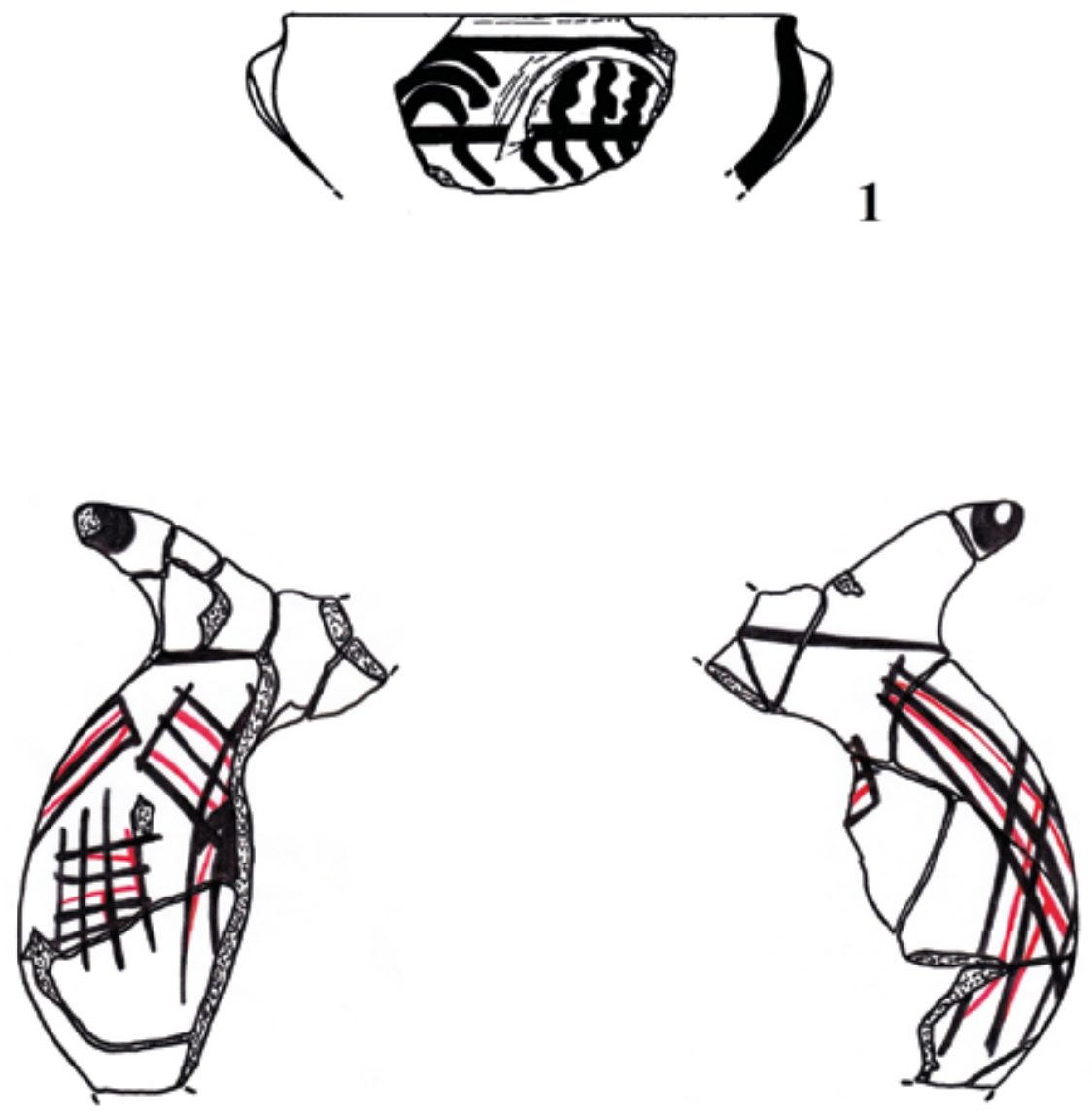

2a-d
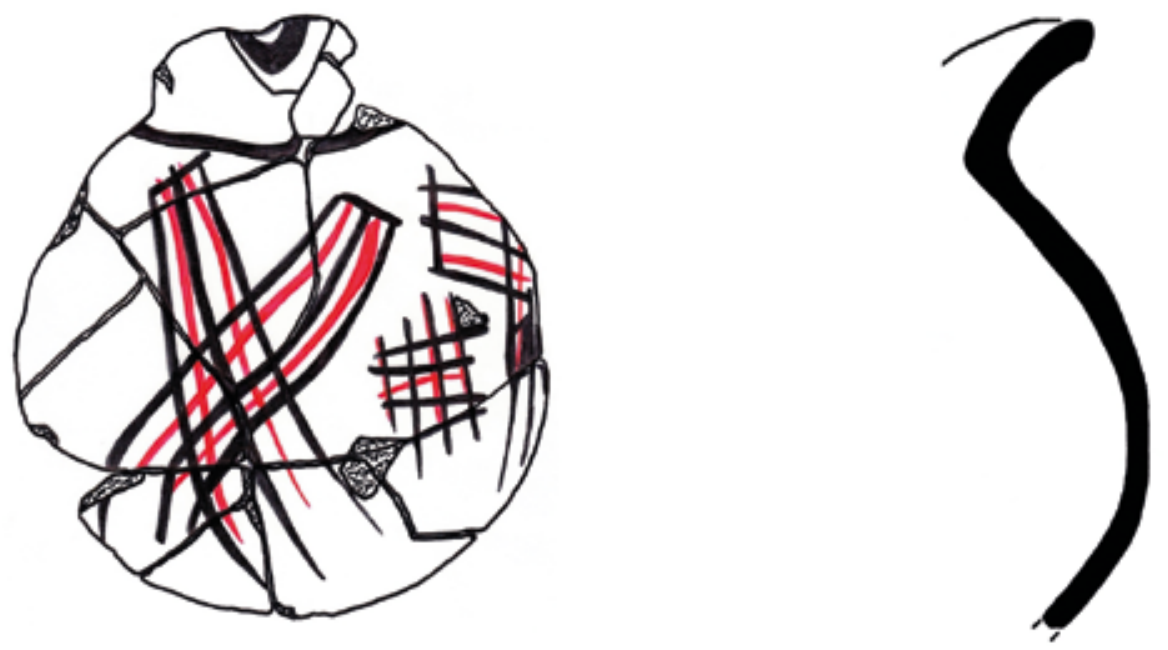

0

$10 \mathrm{~cm}$

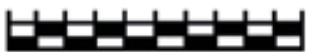

Plate 5: Çayyolu Höyük. Dark- (1) and bichrome-painted (2) pottery / Çayyolu Höyük. Koyu (1) ve iki renkli (2) boyalı çanak çömlekler 

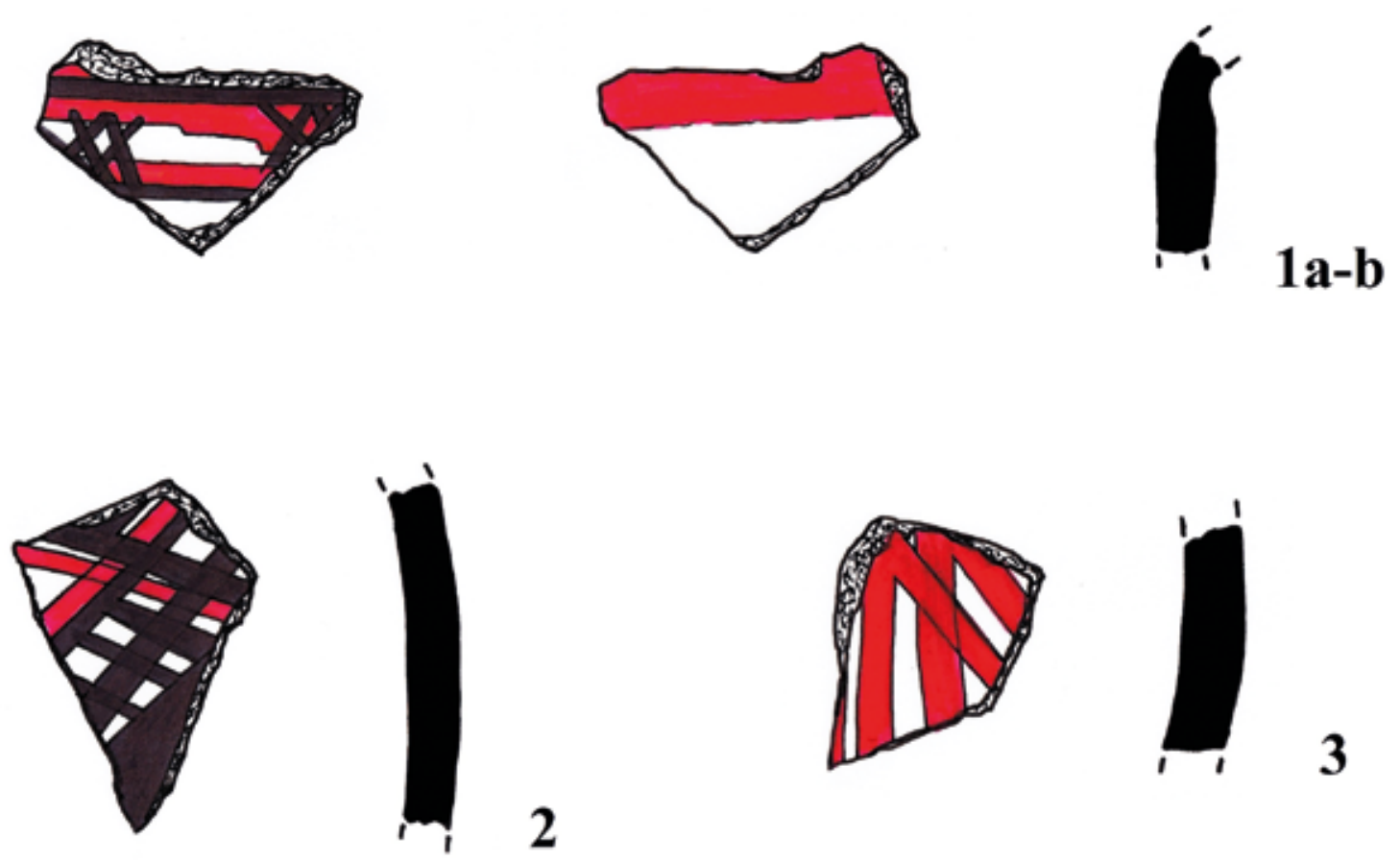

2
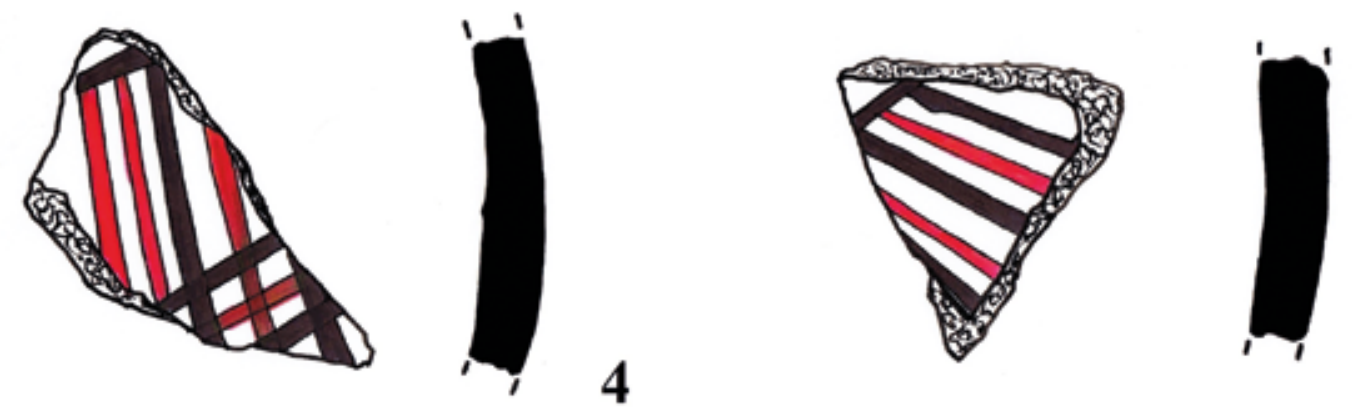

5
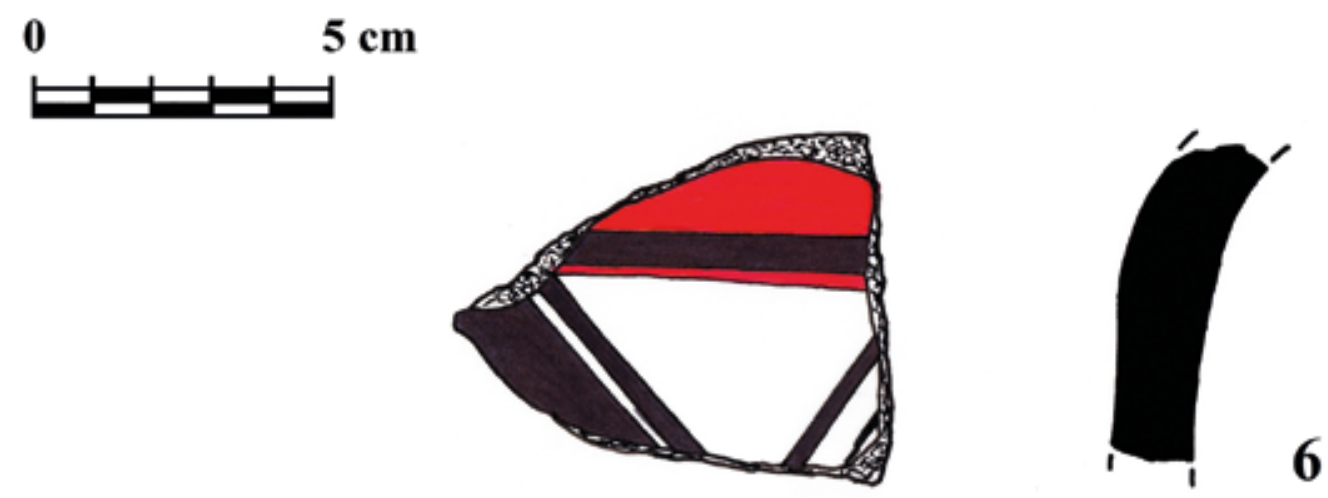

Plate 6: Çayyolu Höyük. Red- (3) and bichrome-painted (1-2, 4-6) pottery / Çayyolu Höyük. Kırmızı (3) ve iki renkli (1-2, 4-6) boyalı çanak çömlekler 
PAINTED POTTERY WEST OF THE KIZILIRMAK
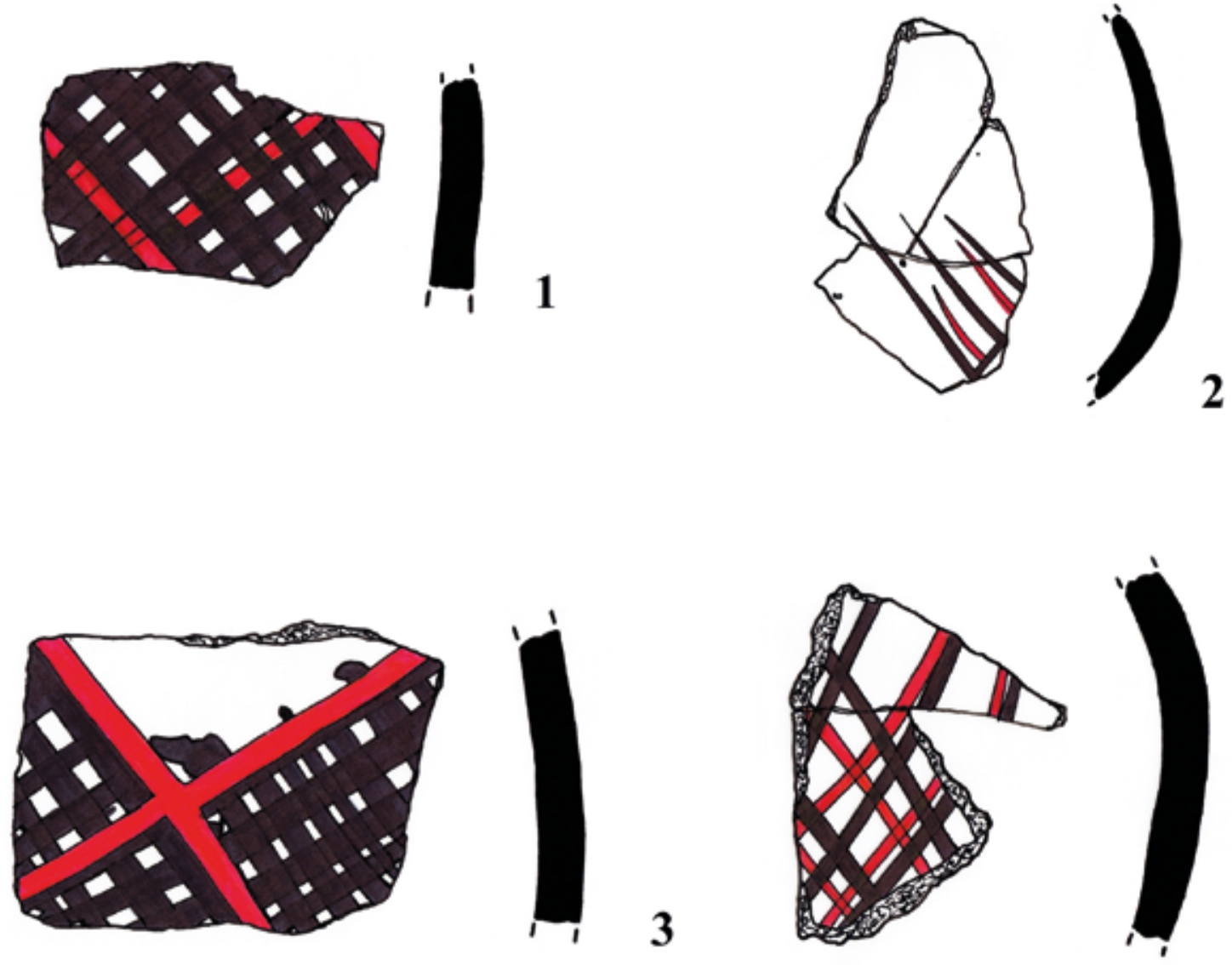

4
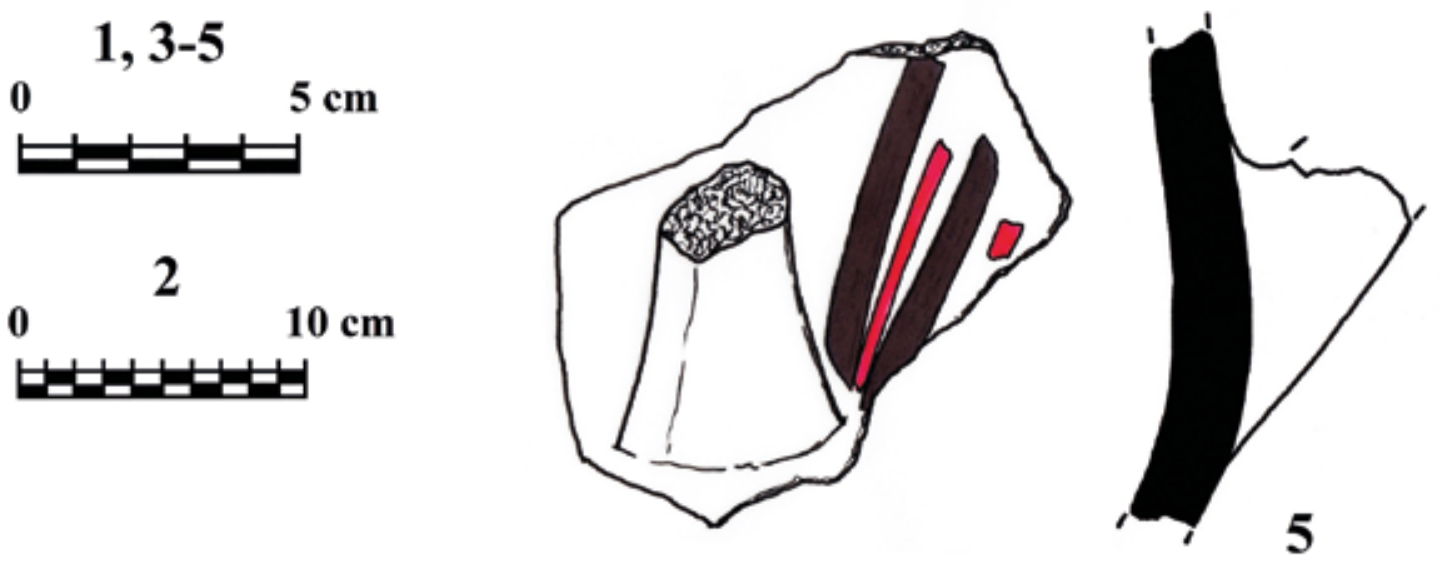

Plate 7: Çayyolu Höyük. Bichrome-painted pottery / Çayyolu Höyük. İki renkli boyalı çanak çömlekler 


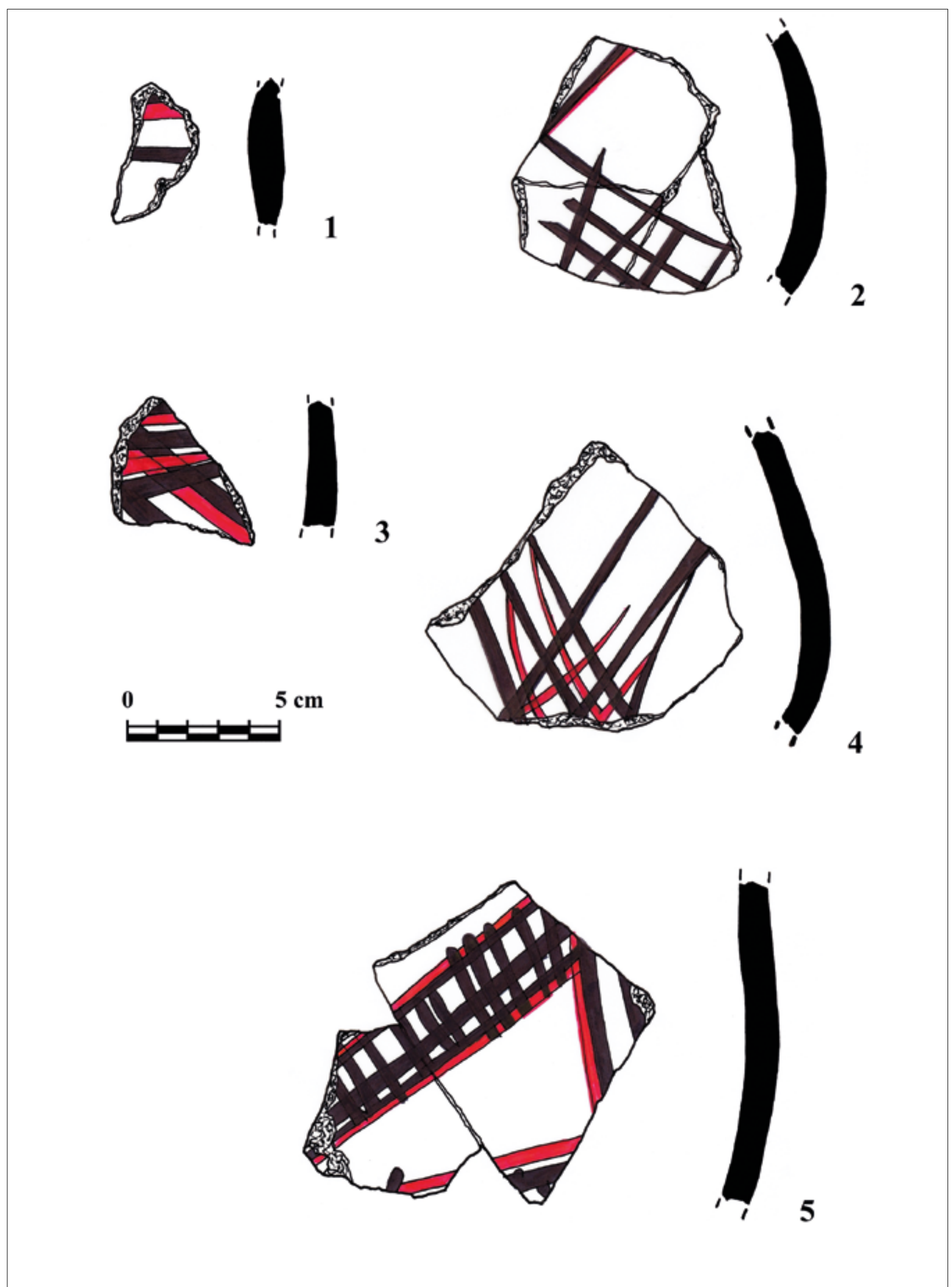

Plate 8: Çayyolu Höyük. Bichrome-painted pottery / Çayyolu Höyük. İki renkli boyalı çanak çömlekler 
PAINTED POTTERY WEST OF THE KIZILIRMAK

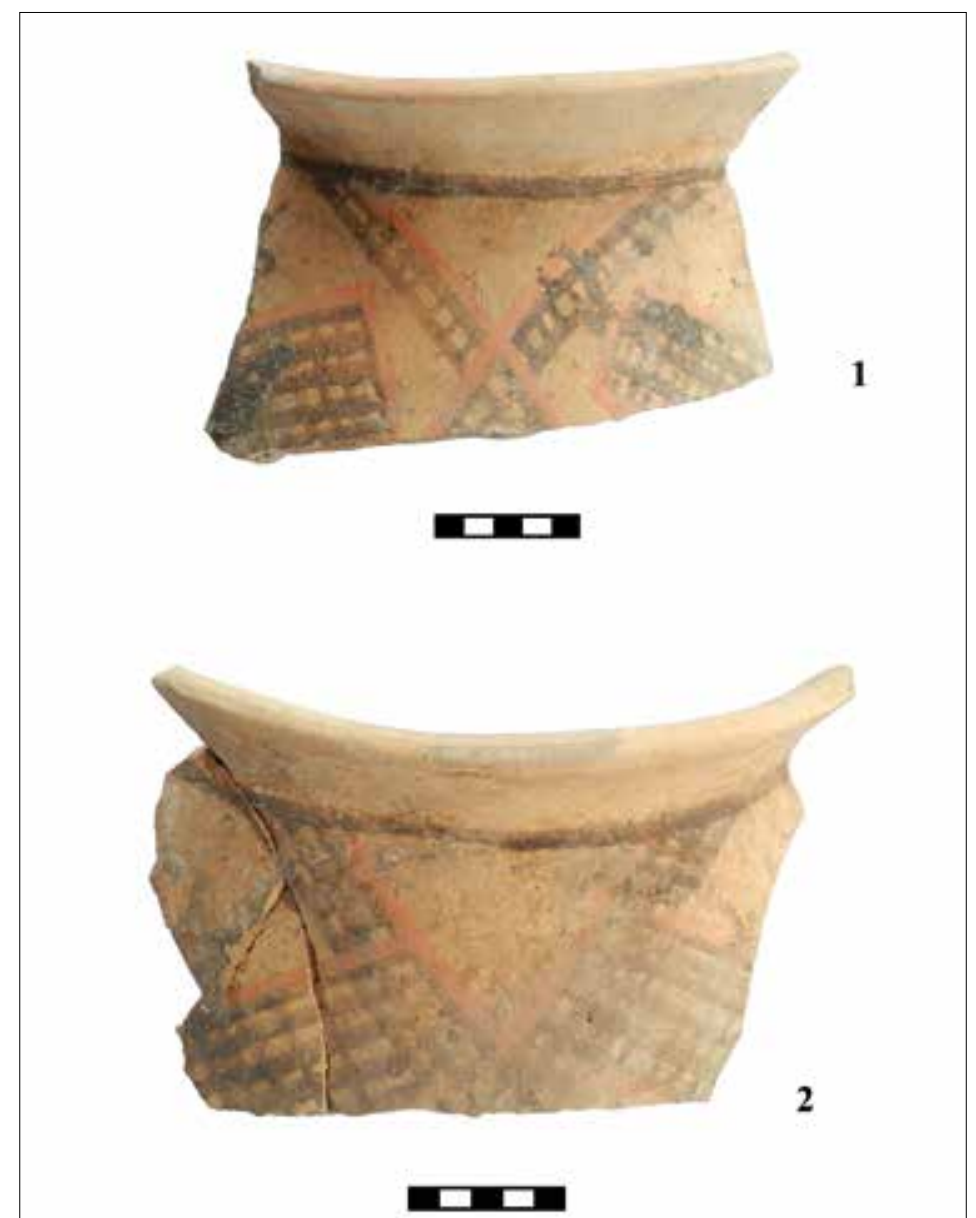

Plate 9: Çayyolu Höyük. Bichrome-painted pottery. / Çayyolu Höyük. İki renkli boyalı çanak çömlekler.

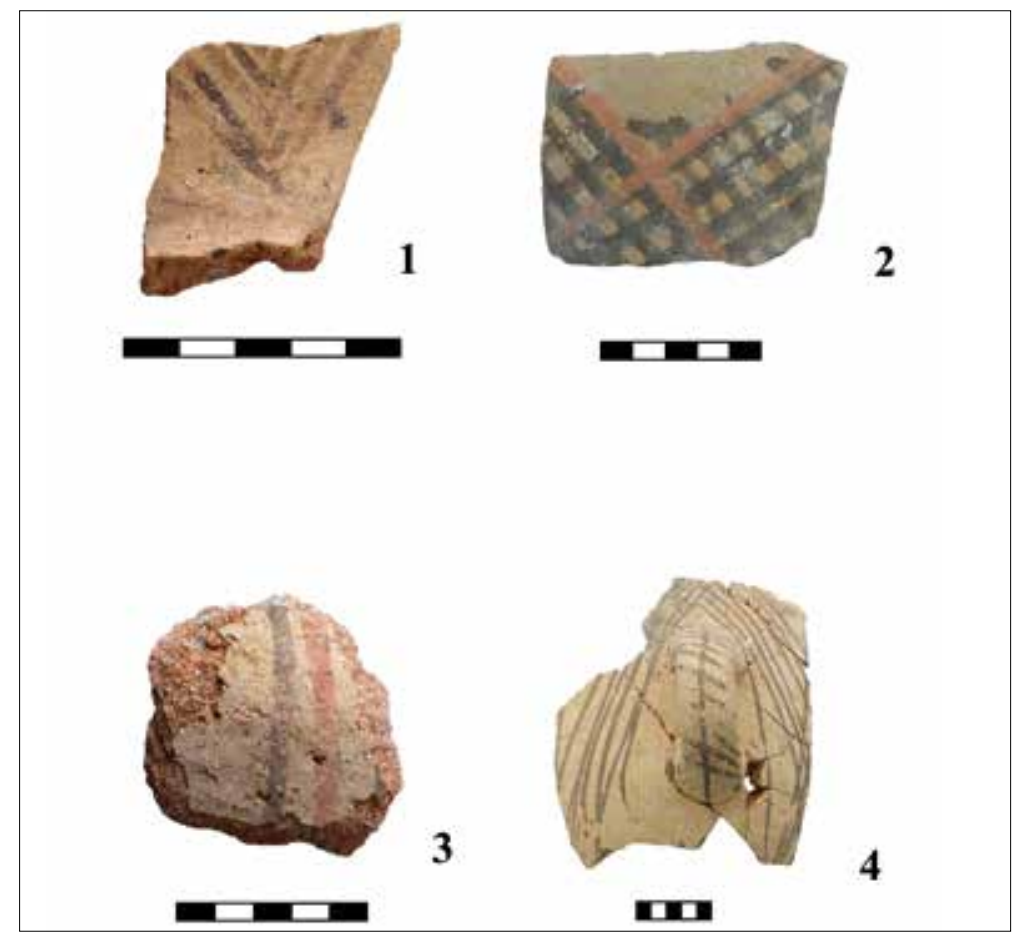

Plate 10: Çayyolu Höyük. Dark- $(1,4)$ and bichrome-painted (2-3) pottery / Çayyolu Höyük. Koyu $(1,4)$ ve iki renkli $(2-3)$ boyalı çanak çömlekler 


\section{SUMMARY}

West of the Kiz1lirmak, dark-painted ceramics are by no means rare. There are numerous vessel remains from Karaoğlan Höyük, Polatlı, Gordion, Külhöyük, and Çayyolu Höyük (Fig. 3). Very often different groups of painted decoration appear. In the first group, we count dark (black, black-brown) painting on a light background. The motifs here are mainly angular bands and groups of lines. There are parallels with the Intermediate ware within the Kızılırmak arch (Alişar, Mercimektepe, Hashöyük, Northwest Slope). However, the best comparisons are from Acemhöyük (layers V to $\mathrm{X}$ ). It is also clear, however, that there are differences to the west of the Kizllirmak in the designs and painting of the finds presented here, so we assume that this is a local feature. Differences mainly concern the quality and painting style, which is much better in the east. It is also noticeable that the ceramics we have presented here have a range of motifs mainly limited to bundles of lines and angular bands. The remains of bichrome-painted vessels also have a local character, which is the reason we refer to them here as Çayyolu Bichrome Ware $A$ and $B$ (ÇBW $A$ and $B$ ). Moreover, we have observed features connecting them to the Alişar III-ceramics. However, there are great differences here as well. The two groups do not exhibit the high-quality work and painting of the Alişar III-pottery. At present, a stratigraphical/chronological difference cannot be clearly recognized among the three painted ceramic groups from Çayyolu Höyük. Rather, the distribution of the ceramics in the layers indicates a more-or-less simultaneous occurrence.

\section{BIBLIOGRAPHY}

ARIK, R.O. 1939.

"Anadolunun En Garp Eti İstasyonu Karaoğlan Höyӥğ̈̈”, Belleten III/9: 27-42.

BERTRAM, J.-K./ILGEZDİ BERTRAM, G. 2018.

"The Later Prehistory of the Ankara Region", Context and Connection. Studies on the Archaeology of the Ancient Near East in Honour of Antonio Sagona. Orientalia Lovaniensia Analecta 268 (Eds. A. Batmaz/G. Bedianashvili/A. Michalewicz/A. Robinson), Leuven/ Paris/Bristol: 847-865.

BERTRAM, J.-K./ILGEZDİ BERTRAM, G. in press. The Late Chalcolithic and Early Bronze Age in Central Anatolia. Introduction - Research History Chronological Concepts - Sites, their Characteristics and Stratigraphies, İstanbul.

DENIZLİ, H./KAYA, V./ÇETİN, N. 2002/2003.

"2002 Yılı Külhöyük Kazı Çalı̧̧maları", Anadolu Medeniyetleri Müzesi 2002 Yıllığı: 5-27.

DENIZLİ, H./KAYA, V./ÇETIN, N. 2006.

"2005 Yılı Külhöyük Kazı Çalışmaları", Anadolu Medeniyetleri Müzesi 2005 Yıllığı: 9-34.

GUNTER, A.C. 1991.

The Bronze Age. Gordion Excavations Final Reports III, Philadelphia.

KAMIŞ, Y. 2012.

Acemhöyük Erken Tunç Çağı Seramiği, Unpublished PhD-Thesis Gazi Üniversitesi, Ankara.

LLOYD, S./GÖKÇE, N. 1951.

"Excavations at Polatli. A New Investigation of Second and Third Millennium Stratigraphy in Anatolia", Anatolian Studies I: 21-75.

ÖKTÜ, A. 1973.

Die Intermediate-Keramik in Kleinasien, München.

ÖZDEMIR, M.A. 2016.

Nevşehir Suluca Karahöyük Demir Çağı Boyalı Seramikleri, Unpublished MA-Thesis Atatürk Üniversitesi, Erzurum.

ÖZGÜÇ, T. 1947.

"Typical Pottery of the Middle Anatolian "Copper" and "Bronze" Ages (New Finds from Kültepe near Kayseri)", Artibus Asiae 10/4: 312-323. 
OMURA, S. 1991.

"Painted Pottery Collected from the Basin of the Delice River in Central Anatolia", Near Eastern Studies. Dedicated to H.I.H. Prince Takahito Mikasa on the Occasion of His Seventy-Fifth Birthday. Bulletin of the Middle Eastern Culture Center in Japan V (Eds. M. Mori/H.Ogawa/M. Yoshikawa), Wiesbaden: 279-292.

ORTHMANN, W. 1963a.

Die Keramik der Frühen Bronzezeit aus Inneranatolien, Berlin.

ORTHMANN, W. 1963b.

Frühe Keramik von Boğazköy aus den Ausgrabungen am Nordwesthang von Büyükkale, Berlin.

ORTHMANN, W. 1966.

"Untersuchungen auf dem Asarcık Hüyük bei Ilıca", Istanbuler Mitteilungen 16: 27-88.

TEMIZSOY, İ./KAYA, V./ÇETIN, N. 2002.

"2001 Yllı Külhöyük Kazı Çalışmaları", Anadolu Medeniyetleri Müzesi 2001 Yıllı̆̆ı: 5-28.

VON DER OSTEN, H.H. 1937.

The Alishar Hüyük Seasons of 1930-32, Part I. Chicago.

YILDIRIM, T. 2014.

"Çorum / Resuloğlu Kazıları 2013 Yllı Sonuçları", 4. Çorum Kazı ve Araştırmalar Sempozyumu: 1-9. 